\title{
Erratum to: Comparison of lymphomononuclear cell energy metabolism between healthy, impaired glucose intolerance and type 2 diabetes mellitus patients
}

\author{
L. Ozsari · H. Boyunaga $\cdot$ N. Karadurmus • \\ M. Sahin · G. Uckaya · A. U. Ural · L. Kenar • \\ M. Kutlu
}

Published online: 25 May 2010

(C) Springer Science+Business Media, LLC 2010

\section{Erratum to: Endocr}

DOI 10.1007/s12020-009-9281-0

Two authors were mistakenly omitted from the original publication. The authors are:
Hakan Boyunaga, MD, Associate Professor, Department of Biochemistry, Kırıkkale Medical Faculty, Turkey (second author) and Levent Kenar, MD, Associate Professor, Department of Medical Cbrn Defense, Gülhane Military Medical Academy, Turkey (seventh author).

The online version of the original article can be found under doi: 10.1007/s12020-009-9281-0.

L. Ozsari · N. Karadurmus

Department of Internal Medicine, Gülhane Military Medical

Academy, Ankara, Turkey

H. Boyunaga

Department of Biochemistry, Faculty of Medicine, Kırıkkale

University, Kırıkkale, Turkey

M. Sahin $(\bowtie) \cdot$ G. Uckaya $\cdot$ M. Kutlu

Department of Endocrinology and Metabolism, Gülhane

Military Medical Academy, Ankara, Turkey

e-mail: drsahinmustafa@yahoo.com

\section{A. U. Ural}

Department of Hametology, Gülhane Military Medical

Academy, Ankara, Turkey

\section{A. U. Ural}

Department of Immunology, Gülhane Military Medical

Academy, Ankara, Turkey

L. Kenar

Department of Medical Cbrn Defense, Gülhane Military Medical

Academy, Ankara, Turkey 